\title{
Comparison of ilmenite-clinopyroxene symplectites from Vitim alkaline basalts and Yakutian kimberlites (Siberia, Russia)
}

\author{
Litasov K.D. ${ }^{1}$, Kostrovitsky S.I. ${ }^{2}$, Litasov Yu.D. ${ }^{1}$ \\ 1. United Institute of Geology. Geophysics and Mineralogy SB RAS. Novosibirsk. 630090. Russia \\ 2. Institute of Geochemistry SB RAS, 664033. Irkutsk. Russia
}

The ilmenite-clinopyroxene symplectites (also called as graphic or lamellar intergrowth) are rare among xenoliths from kimberlite. They are scarce as well among the xenoliths from the other related rocks such as Malaita alnöites (Nixon, Boyd, 1979). Previous studies allowed to consider the symplectites to be in relation with $\mathrm{Cr}$-poor megacryst assemblages according to mineral chemistry and various polymineral inclusions. We found similar ilmenite-clinopyroxene symplectite nodules in

Miocene picrobasalts and Quaternary basanites of the Vitim volcanic field (Baikal Rift, East Siberia) (Litasov, Ashchepkov, 1996). It was the first finding of such xenoliths in Cenozoic alkaline basalte areas. The composition of minerals is also similar to discrete megacrysts.

For a comparative study of ilmenite-clinopyroxene intergrowths from kimberlites and alkaline basalts, we drew the data on xenoliths from Yakutian kimberlites (Mery pipe, Kuoisk field, and Mir pipe, Malo-Botuobinsk field) and the Vitim volcanics. Compositional variations in symplectitic ilmenites revealed likeness of symplectites from alkaline basalts with those from kimberlites (Fig.1). Ilmenite megacrysts and symplectites from kimberlites are more magnesian than ilmenites from alkaline basalts. Ilmenite from symplectites plots to the most magnesian end of a megacryst trend.

Clinopyroxene from
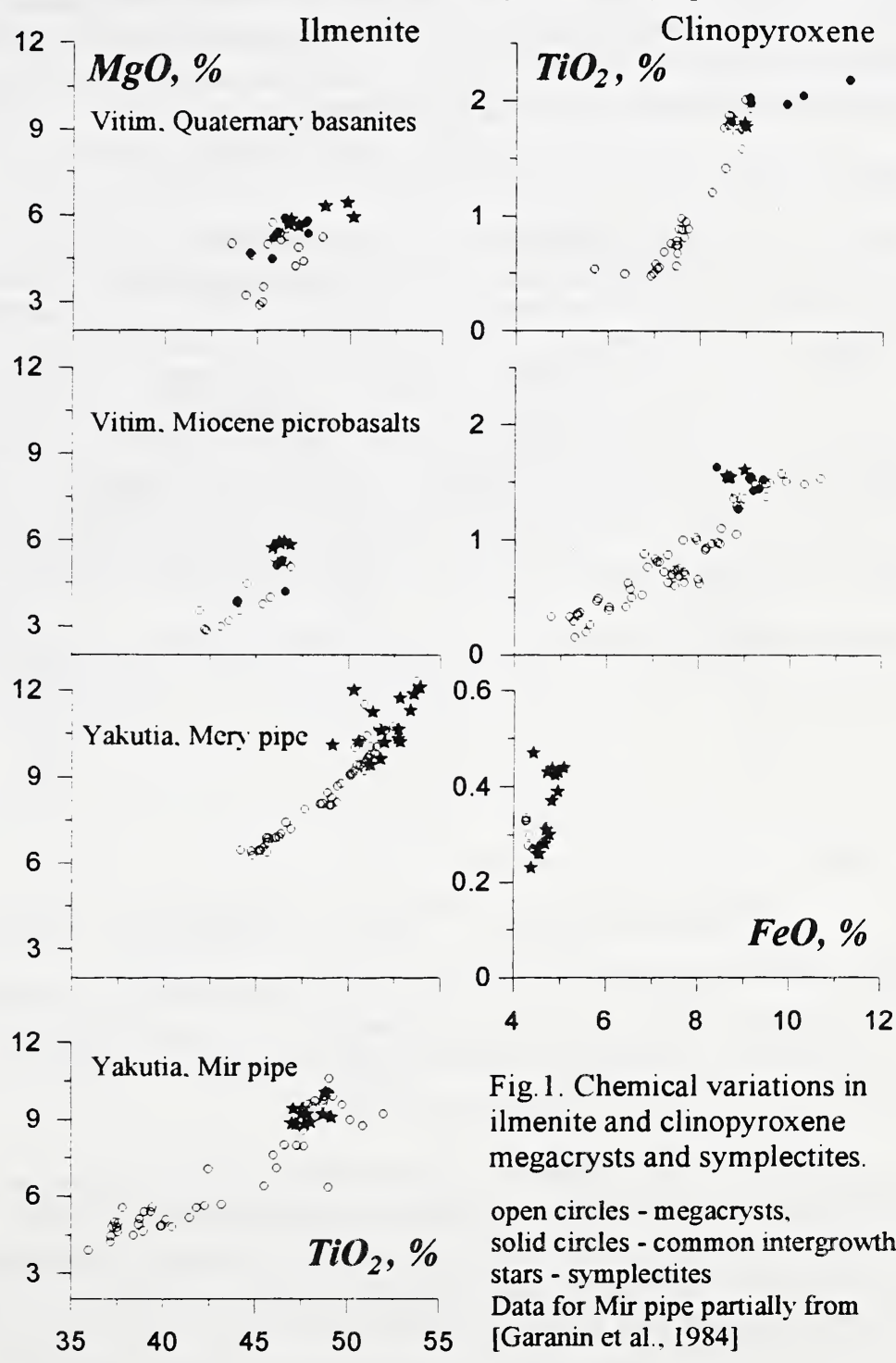

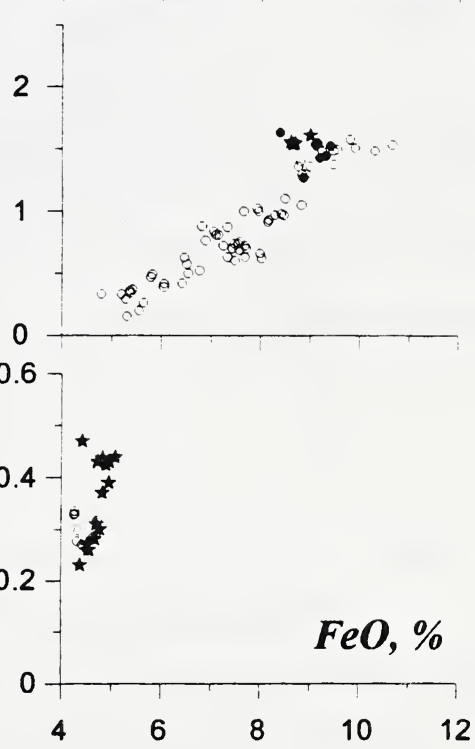

Fig. 1. Chemical variations in ilmenite and clinopyroxene megacrysts and symplectites.

open circles - megacrysts, solid circles - common intergrowths, stars - symplectites

Data for Mir pipe partially from [Garanin et al., 1984] 
alkaline basalts corresponds to ferriferous end of the megacryst trend. The beginning of ilmenite precipitation is marked by inflection of $\mathrm{Ti}-\mathrm{Fe}$ trend in the variation diagram (Fig. 1). Clinopyroxene from symplectites plots near inflection, and it is more magnesian than common ilmeniteclinopyroxene intergrowths. Clinopyroxene from Mery symplectites is divided into two groups. Low-Ti clinopyroxene forms a short trend similar to discrete megacryst trend. There is an evident dependence of $\mathrm{Ca} \#$ and $-\mathrm{Mg} \#$ variations in clinopyroxene and $\mathrm{Mg}$-number in ilmenites (Kostrovitsky, Piskunova, 1989). These data are in agreement with other kimberlite locations (Gurney et al., 1979, Shulze, 1987), for example, Ti-trend inflection is shown for a garnet from xenoliths of the Monastery pipe (Shulze, 1987).

Trace element variations in megacryst and symplectite clinopyroxene are shown in Fig. 2 . Data for clinopyroxene megacrysts from kimberlites are insufficient yet. However, we can note similar patterns for symplectite clinopyroxene in both kimberlites and basalts with more depleted HREE in kimberlitic one. If we consider a fractional crystallization of melt coexisting with most primitive Vitim clinopyroxene (Fig.2) with clinopyroxene-only precipitation, estimated residual melt fraction reaches $f=10-15 \%$ for ilmenite-clinopyroxene intergrowths from Quaternary basanites and $f=20-25 \%$ for Miocene picrobasalt symplectites.

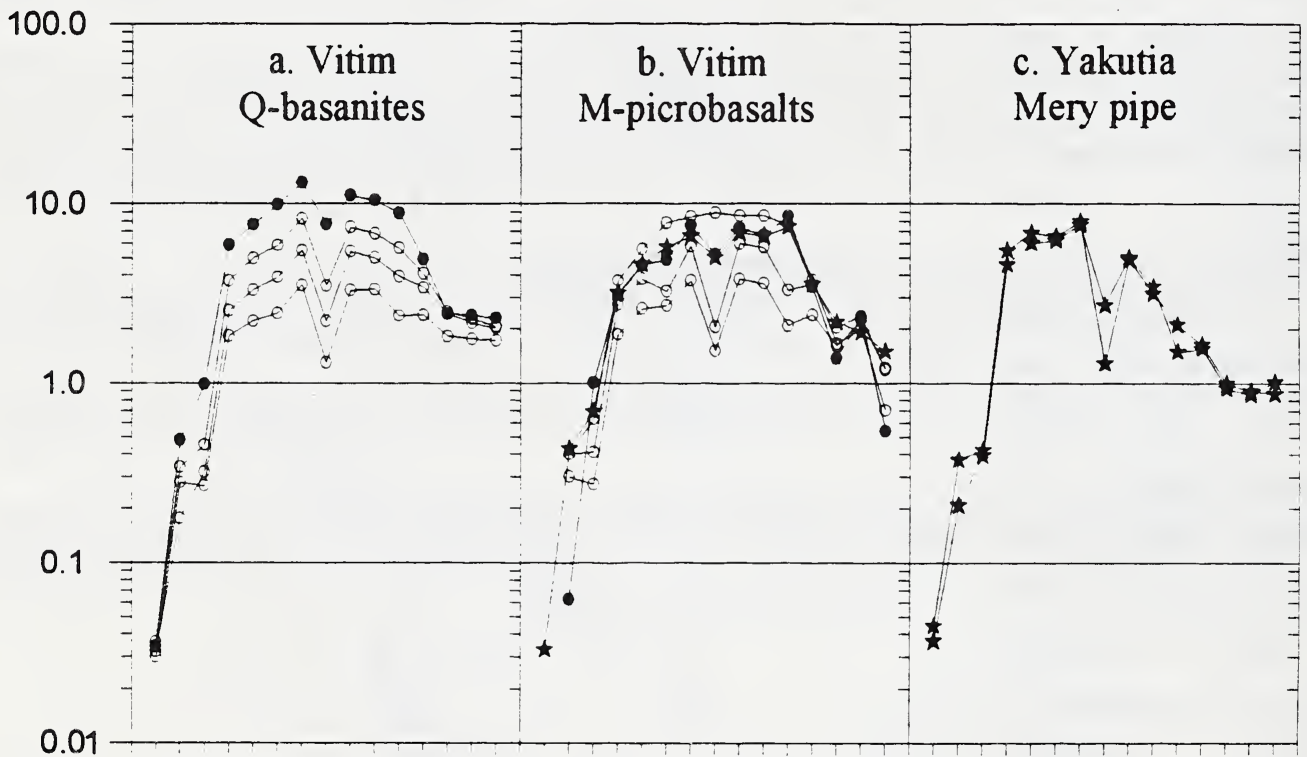

$\mathrm{Ba} \mathrm{Nb} \mathrm{Ce} N d \mathrm{Sm}$ Ti $\mathrm{Er}$ Yb Ba Nb Ce Nd Sm Ti Er Yb Ba Nb Ce NdSm Ti Er Yb Th La Sr Zr Eu Dy Y Th La Sr Zr Eu Dy Y Th La Sr Zr Eu Dy Y

Fig.2. Partitioning of trace element in clinopyroxene from megacrysts and symplectites.

For symbols see Fig. 1. Analyses are made by ion microprobe. ICP-MS-data for megacrysts in b are taken from [Ashchepkov, Andre, 1998]. Trace element abundances are normalized to primitive mantle [McDonough, Sun, 1995].

Structure and chemistry of sypmlectites from kimberlites allows to suggest their crystallization from kimberlitic melt before the crystallization of discrete ilmenite nodules (Gurney et al., 1979; Kostrovitsky, 1989). Wyatt's experiments showed a possibility for eutectic precipitation of clinopyroxene and ilmenite after a clinopyroxene-only crystallization (Wyatt, 1977). The possibility of ilmenite formation as a dissolution lamellae might be excluded due to high modal primary ilmenite (up to $15-20 \%$ ) in symplectites and megacryst-like trace element variations in clinopyroxene. 
Moreover, we can observe simultaneous growth straie on clinopyroxene and ilmenite grains in Mery pipe symplectites.

From estimated residual melt fraction after the symplectite precipitation in the Vitim area, we suppose, that eutectic clinopyroxenes must be more evolved than observed ones. Ilmeniteclinopyroxene symplectites characterize the begining stage of simultaneous mineral precipitation in both kimberlites and alkaline basalts. Transitions from symplectite to common intergrowth within a single sample give an evidence for their kinship. Thus, the ilmenite-clinopyroxene symplectite formation can not be explained by simple eutectic crystallization and calls for some specific conditions of melt fractionation.

Acknowledgments. We thank Dr. A.V.Sobolev for providing ion microprobe analyses and Dr. S.Z.Smirnov for critical discussion. This work is supported by RFBR grant No97-05-65309.

\section{References}

Ashchepkov, I.V., and Andre, L., 1998, Mantle-seated differentiation of alkaline mantle melts beneath the Vitim plateau (Siberia, Russia): the role of garnet: Journal of Petrology, in press.

Garanin, V.P., Kudryavtseva, G.P., and Soshkina, L.T., 1984, Ilmenites from kimberlites: Moscow University Press, 239p. (In Russian).

Gurney, J.J., Jakob, W.R.O., and Dawson, J.B., 1979, Megacrysts from the Monastery kimberlite pipe, South Africa: «The mantle samples: inclusions in kimberlites and other volcanics», Proc. 2th Int. Kimb. Conf., p. 227-243.

Kostrovitsky, S.I., and Piskunova, L.F., 1989, Two group of symplectites from one kimberlite pipe: Transactions (Doklady) of Russian Akademy of Science, v.306, p. 1213-1216.

Litasov, K.D., and Ashchepkov, I.V., 1996, Ilmenite megacrysts and ilmenite-bearing pyroxenites from alkaline basalts, Vitim plateau: Russian Geology and Geophysics, v.37, №7, p.97-108.

McDonough, W.F., and Sun, S.S., 1995, The composition of the Earth: Chemical Geology, v. 120, p.223-253.

Nixon, P.H., and Boyd, F.R., 1979, Garnet-bearing lherzolites and discrete nodules from the Malaita alnoite, Solomon Islands, S.W.Pacific, and their bearing on oceanic mantle composition and geotherm: «The mantle samples: inclusions in kimberlites and other volcanics», Proc. 2th Int. Kimb. Conf., p. 400-423. p.433-452.

Shulze, D.J., 1987, Megacrysts from alkaline volcanic rocks: In P.Nixon ed., Mantle Xenoliths, Wiley, NW,

Wyatt, B.A., 1977, The melting and crystallization behavior of a natural clinopyroxene-ilmenite intergrowth: Contributions to Mineralogy and Petrology, v.61, p.1-9. 